\title{
Foreign Capital for Development: The Constraints of Foreign Borrowing with Particular Reference to Algeria's Case
}

\author{
By Abdelhafid Aimar*
}

\begin{abstract}
The paper examines the major advantages and disadvantages of foreign capital in the form of foreign "aid" and private loans. It discusses Algeria's case as an oil producer and exporter which relied heavily on external resources to help finance its ambitious public investment programmes and achieve a self-sustained growth. The main concern is to examine the constraints of foreign borrowing and its repercussions on Algeria's development. It assesses the various measures the Algerian government took to deal with the far-reaching effects of the oil crisis of 1986 and the foreign debt burden. It further highlights the major setbacks of Algeria's development and asks why the growth of the country's economy remained low and dependent on oil and gas revenues after more than half a century of development? It finally concludes the prominent lessons to be learnt from the Algerian development experience.
\end{abstract}

Keywords: Algeria, Developing countries, Economic development, Foreign capital, Foreign debt

\section{Introduction}

In the wake of independence, the economies of developing countries were structurally distorted and lacked strong domestic bases for capital accumulation. This prompted discussions over the possibility of using foreign resources to boost economic growth and development. In the beginning, many developing countries rejected the use of foreign capital in economic development, seemingly for historical, ideological and strategic reasons, and opted for mutual trading arrangements and self-reliance.

However, the inherited underdevelopment and dependency relations and an unjust world economic order seemed to have made it difficult, if not impossible, for developing countries to implement their national options. They lacked not only financial resources but also the necessary human and technical means to initiate the development process. This unfavourable internal and external environment pushed many of them to adopt more pragmatic approaches in dealing with economic development and foreign cooperation and they eventually accepted recourse to foreign resources.

The use of external resources was stimulated by the successful experience of the Marshall Plan which contributed to the reconstruction of Western Europe after World War II and later by the views that development could be speeded up by an increase in the rate of investment through foreign capital. It

*Associate Professor, University of Jijel, Algeria. 
was argued that foreign capital could serve as an instrument to the relief of economic bottlenecks such as balance-of-payment deficits and financial shortages. It was claimed that foreign resources would make the requirements for coordinated changes in the economy less stringent and would contribute to a fuller use of domestic resources.

This paper examines the major advantages and disadvantages of foreign capital in the form of foreign "aid" and private loans. It begins with a brief study of views concerning foreign capital and its benign and malign role in the process of economic growth and development. It asks if external resources substitute or complete domestic savings? It further seeks to reveal whether reliance on foreign capital makes growth faster in the long run. It discusses Algeria's case as an oil producer and exporter which relied heavily on external resources to help finance its ambitious public investment programmes and achieve a self-sustained growth. The main concern of this paper is to examine the constraints of foreign borrowing and its repercussions on Algeria's development. It assesses the various measures the Algerian government took to deal with the far-reaching effects of the oil crisis of 1986 and the foreign debt burden. It further highlights the major setbacks of Algeria's development and asks why the growth of the country's economy remained low and dependent on oil and gas revenues after more than half a century of development? It finally concludes the prominent lessons to be learnt from the Algerian development experience.

\section{Foreign Capital Views and Arguments}

The colonial legacy of developing countries was significantly cumbersome. They essentially inherited underdevelopment and distorted economic structures entirely tied to the colonial powers. In the wake of independence, their economies were stagnant and lacked a strong domestic basis for capital accumulation. To transform the inherited structural imbalances, developing countries needed coherent development policies to better allocate their resources and orientate their economies to the satisfaction of their domestic needs.

In the early years of independence, developing countries refused recourse to foreign resources and sought to establish mutual trading arrangements instead. They viewed foreign capital as a new form of colonialism and, therefore, must be avoided to preserve their political independence. However, a world bank commission report (as cited in Brown 1974: 200) later announced that they "received the definite impression that most low-income countries would welcome a larger flow of foreign investment, sharing the belief that such flows would contribute to faster growth". This change in policies was apparently the result of underdevelopment, dependency relations with western economic powers and the inability of developing countries to exert, at that stage, any major influence to alter the existing world economic order. 
The belief that developing countries needed foreign resources to promote development was first stimulated by the successful experience of the Marshall Plan which contributed to the reconstruction of Western Europe after World War II and, then, by the views that development could be speeded up by an increase in the rate of investment. The rate of investment as a prime factor in determining the rate of growth was emphasized by Harrod and Domar's formulation and by R. Nurkse's theory of vicious circles. The latter argues that developing countries lack the capability to increase savings to induce investment. In Nurkse's view as (cited in Symonds 1970: 200) foreign capital is required for development; it provides the impetus for a high rate of income growth which, in turn, increases the rate of marginal savings so that the savings rate would sooner or later catch up with the rate of investment. Thus, foreign capital is regarded as a driving force for development and was supposed to subsequently lead to self-sustained growth.

Nevertheless, it is essential to note that some of the advocates of foreign capital distinguish between the roles of its various forms: grants, government loans, commercial loans and direct investment. For instance, Bauer (1971) strongly opposes the idea of "aid" (grants and governmental loans). He argues that "aid" is plainly not necessary for development as it is shown by the progress of many poor countries without it, such as Hong Kong. He believes that development depends on peoples' capacities, motivations and social and political institutions. Where these basic determinants are favourable, material progress will usually occur. In his view, "aid" promotes the adoption of foreign models which are unsuitable to the requirements of development. He holds that "aid" politicizes life and diverts energy and ambition from economic activity and exacerbates political tensions.

While opposing foreign "aid", however, Bauer (1971) favours foreign private capital. He stresses that capital is less productive than if it were supplied commercially from abroad to government or to business. Thus, Bauer appears to argue that what is vital for the development of developing countries is private foreign capital rather than "aid". This reflects the Eurocentric view of development; seventeenth century Europe did not need "aid" to grow. However, this analysis ignores the transfer of wealth to Europe through the exploits of merchant capitalists and which is still being done through multinational corporations and the workings of the world economic system.

The argument that foreign capital is needed for the development of newly independent countries has been rejected by some scholars; they see no positive association between growth and reliance on foreign capital. For instance, Prasad et al. (2006: 1-11) argue that in non-industrial countries "foreign capital by itself would not generate much additional growth". They maintain that there is "a strong positive correlation suggesting that countries that rely less on foreign capital grow more" and "countries that have relied more on foreign capital have not grown faster in the long run, and have typically grown more slowly". They referred to China which has been growing fast, while it was a net exporter of capital over the period 1970-2004 and continues to be a large investor abroad. More importantly, they stressed that it is countries that have 
higher savings for a given level of investment that experience higher growth. This implies that domestic savings rather than foreign savings are vital in the growth process of developing economies.

Similarly, other academics like Korinek (2010) urge restrictions of foreign capital inflows to developing countries. In this context, Korinek (2010) argues that "capital inflows to emerging markets produce externalities that make such economies more prone to financial instability and crises". He notes that governments in emerging markets can improve their economies by "regulating and discouraging the use of risky forms of external finance, in particular shortterm dollar-denominated debts". Moreover, Dornbusch et al. (1994) and Dornbusch et al. (1995) warn policymakers of the risks of foreign short-term credits as they result in larger slowdowns in capital flows. They hold that when maturity periods are shorter a country's debt becomes more prone to sudden stop crises. They sustain that a slowdown in capital flows usually generates severe drops in output, private spending and credit to the private sector, and real exchange rate depreciation. This often results in either a loss of international reserves and/or a lower current account deficit, both of which have negative effects on the domestic economy.

More radically, the neo-Marxist theory emphatically criticized the need for foreign capital and regarded the export of capital to developing countries as a new form of colonialism. They argued that capital exports are not a real transfer of resources needed to boast growth in developing countries; they essentially serve to promote economic dependency to western powers. Hayter (1971), an exponent of this radical view, looks to foreign capital as a mere vehicle to further the underdevelopment of developing countries. She particularly claims that foreign capital acts as an instrument that has strong influence on the direction in which developing economies will go, a direction most suited to the interests of capitalist powers.

The neo-Marxists further criticize the social and political aspects of foreign capital in developing countries. They argue that foreign capital, in its various forms, is used to prop up unstable governments whose continued existence is to the strategic interest of the West. Foreign capital creates a ruling bourgeoisie loyal to western powers and oppressive to any attempts by poorer people in developing countries to challenge the status quo (Webster 1984: 165). Thus, in their view foreign capital is not allocated to foster growth and change in developing countries but rather to maintain the existing conditions and dependency relations in developing countries.

However, while firmly opposing foreign capital flows to developing countries, the neo-Marxist view does not appear to provide an answer to the problems of developing countries. Indeed, it implies that the economies of these countries are to remain stagnant and, therefore, undeveloped. They seem to suggest for developing countries an independent and self-reliant pattern of development.

Practically speaking, foreign capital in most developing countries proved to be less effective, if not ineffective, in relieving bottlenecks and stimulating development. Indeed, external capital flows in developing countries have done 
little to eradicate the major structural imbalances inherited from the colonial era. In fact, these have frequently been aggravated and further problems have been generated. Despite the emergence of some newly and semi-industrialized economies, the great majority of developing countries are still lagging behind in terms of economic, technical and scientific progress and many of them are still politically and/or economically tied to the west with new dependency relationships: technological dependence and foreign debt.

Moreover, considerable funds have been transferred annually, legally or illegally, from developing countries to developed countries. In a study released by Global Financial Integrity (GFI), Danziger (2010) indicated that developing countries lose roughly US\$ 1trillion per year through illicit capital outflows. This is compared to a mere US\$ $100 \mathrm{bn}$ of annual official "assistance" to developing countries. In other words, developing economies lose US\$10 through illicit means for every US\$1 of foreign "aid" that they receive. Furthermore, in a latest GFI report, Kar and Spangers (2014) revealed that illicit financial flows from developing and emerging economies totalled US\$ 6.6bn over the period 2003-2012. They pinpointed that illicit outflows are increasing at a staggering annual rate of $9.4 \%$. This empirical evidence clearly goes against the view that developing countries lack the necessary domestic savings to carry out investments. Rather, savings are being drained substantially from these countries and this is undoubtedly impeding their economic and social development.

To defend their views and arguments, the advocates of foreign capital tried to relate its failures in developing countries to internal factors. They argued that foreign capital problems are the result of mismanagement, deficient development policies and corruption. While this is true, it connot be denied that external factors have also been behind developmental setbacks in many developing countries. Foreign funds have been allocated not only on the basis of inducing economic growth, but also on the basis of other considerations. Indeed, they have been allocated to serve other self-interest motives: strategic, political, commercial and cultural.

Moreover, foreign funds have frequently gone to those developing countries which have reached a relative level of development, instead of those countries which do not possess adequate resources to finance development. In this respect, Webster (1984) revealed that only $18 \%$ of Western "aid" was received by the least developed countries during 1980-1981. But this view has been opposed by Prasad et al. (2006). They stated that it was not true that amongst non-industrial countries, the most productive get the most capital inflows. In fact, foreign capital has been oriented to those countries rich in raw materials and capable of paying back the loans and likely to be markets for manufactured goods from developed countries.

Foreign funds have also served to develop infrastructures and mining to facilitate the penetration of foreign companies into developing countries and to satisfy the needs of the economies of industrialized countries. Indeed, foreign capital flows to developing countries have helped western economies and businesses to expand and flourish. Considerable profits have been, and still are, 
transferred annually from developing countries to be invested home in the creation of jobs and to serve other purposes. Higher interest rates on loans have been one of the mechanisms of this transfer of wealth. They have not only increased the cost of borrowing but have also contributed to the foreign debt crisis in many developing countries. It cannot be denied that foreign debt has frequently worked as an external sponge on the economies of developing countries.

It should also be noted that foreign capital has been directed to serve political purposes. For instance, it has been used to prop up undemocratic regimes and influence development policies. Thus, foreign capital flows to developing countries are by no means limited to the view of speeding up development. Mcinlay and Little (as cited in Maizels and Nissanke 1984: 883) have summarized the various motives and interests of foreign funds suppliers in five broad categories:

- maintenance of a sphere of interest;

- discouraging associations with communist powers;

- power politics;

- economic development and performance;

- political stability and democracy.

\section{Algeria's Development Policies}

Similarly to other developing countries, Algeria inherited from the French colonial period underdevelopment and an economy almost entirely integrated into France's economy. This situation was exacerbated by the massive outflows of private capital and the exodus of European skilled workers and entrepreneurs during the early years of independence (1962-1965).

To develop its economy and organize its society, Algeria opted for a socialist approach and a self-reliant and inward-looking development model. But it needed to mobilize external financial and technical resources to initiate a process of internal development. However, while recognizing the need for foreign resources, Algeria insisted on their use within the framework of the government's development options and the exclusion of any idea of assistance. Algeria sought to control more closely the exploitation of domestic and foreign resources and the management of its economy. It rejected all forms of dependent economic development and the unjust international division of labour.

Algeria's development experience is the case of a rentier State using the revenues of natural resources, mainly oil and gas, to finance its development programmes. Algeria also provides the example of a country sacrificing the present for the future. It dedicated more than $40 \%$ of its GDP to investment. Moreover, it borrowed extensively on the world financial market and from international and regional aid agencies to help finance the massive import of industrial equipment, in an attempt to build a diversified industrial basis, with 
heavy industries playing the major role, and to stimulate the development of a modern economy.

Nevertheless, the implementation of Algeria's development programmes faced tremendous difficulties and resulted in serious economic and social problems. Furthermore, oil and gas earnings contributed to an easy life which led to devastating effects on sectors like agriculture and the country's productive capabilities. This has significantly contributed to Algeria's falling in the foreign debt trap since the mid-1980s, following the collapse of oil prices in 1986.

\section{Foreign Borrowing in Algeria's Investment Programmes}

Algeria's massive foreign borrowing has been driven by the 1966-1979 development strategy which sought to restrict foreign direct investment in order to avoid foreign domination over the country's economy. This strategy gave priority to heavy and capital intensive industries, such as iron and steel, mechanical and electrical industries, and petrochemicals. Indeed, the implementation of this development strategy required considerable foreign external resources and resulted in huge foreign trade deficits. Foreign borrowing has also been encouraged by substantial increases in oil prices during the 1970s. According to Mutin (1999), these climbed from US\$ 1.80 to US\$ 35 per barrel, resulting in important oil earnings for the government. This borrowing policy carried risks and proved to be very costly since the mid1980s when the oil prices plummeted.

Moreover, according to a report issued by Algeria's Ministry of Planning (MPAT 1980: 291) borrowing abroad has been backed by a dominant Algerian view arguing that it is "suitable and possible" to speed up, in real terms, the rate of Algeria's domestic capital accumulation through the mobilization of foreign capital. But this same view stressed that foreign capital must be regarded as a temporary complement to Algeria's export resources and its role should be limited to avoid falling under its control. The primary object of foreign borrowing was to contribute to the establishment and to the increase of Algeria's funding capabilities, particularly through the development of oil and gas exports.

For this purpose, Algeria carried out a process of heavy borrowing which was further encouraged by an easy access to foreign capital because foreign creditors viewed Algeria a solvent country. By the end of 1979, Algeria ranked the fifth world's debt servicing country after Brazil, Mexico, Venezuela, and Spain, with an estimated disbursed foreign debt of US\$15bn and a debt ratio to exports of $26.3 \%$. After decreasing to about US\$ 13bn in 1983, Algeria's foreign debt climbed once again to US\$ $18 \mathrm{bn}$ in 1986 and further rose to about US\$27bn in 1990 (Mutin 1999).

Algeria's heavy foreign borrowing has also been aggravated by cost overruns in public investments and the practices of foreign companies. For instance, the Arzew gas plant (GNL1) cost three times the original estimate 
(ARB 1980: 5591). It was also the outcome of steady increases in the prices of imported goods because of world inflation and world food shortages. In 1973, for example, Algeria paid four times as much as in 1972 for its wheat imports, three times for timber and more than twice as much for iron and steel products (ARB 1974: 3066). The sharp increases in the prices of imported goods eroded the purchasing power of Algeria's oil revenues and weighed heavily on the government's recurrent and capital expenditures. The purchasing power of the country's exports was further affected by the deterioration of the US dollar which lost about $11 \%$ of its purchasing power in 1974.

By mobilizing domestic and external resources, Algeria was able to carry out unprecedented investment programmes. Over the period 1963-1979 (MPAT 1980), Algeria's public investments were estimated to have totalled nearly AD 300bn (some US\$ 75), of which more than AD 150bn were in hard currency. A further total of AD 350bn (some US\$ 76bn) was reported to have been invested between 1980 and 1984, and another total of AD 550bn (some US\$ 110bn) were planned to be invested over the period 1985-1989 (MPAT 1986). These public investments were financed by oil and gas revenues, the remittances of emigrant workers, mainly in France, foreign funds and money issued by the Algerian central bank.

\section{The Share of Foreign Borrowing in Public Investments}

The lack of a strong domestic basis for capital accumulation has driven Algeria to predominantly rely on external resources in funding development programmes. These external resources were mainly composed of oil and gas earnings, emigrant workers' remittances and foreign borrowing. Over the period 1967-1977, the share of external resources evolved as follows (ONS 1984, Palloix 1980: 531-555):

- $79 \%$ for the period $1967-1969$;

- $60 \%$ for the period 1970-1973;

- $77 \%$ over the period $1974-1977$.

However, the share of foreign borrowing of Algeria's public investments rose steadily over the same period. It evolved as follows (Palloix 1980, SEP 1975):

- $6 \%$ during 1967-1969;

- $16 \%$ during 1970-1973;

- $22 \%$ during 1974-1977.

These shares of external financial resources clearly point to Algeria's heavy dependence on the world market for the financing of development programmes. This financial dependence is subject to the fluctuations of the world market in its three variables: 
- the world labour market (emigrant workers);

- the world financial market (international loans);

- the world oil and gas market (oil and gas prices).

This three-fold financial dependence on the world market puts Algeria in a much vulnerable position with its foreign partners as it affects its public finances and development. Algeria's reliance on the world labour market, mainly France, is of political and economic significance as emigrant workers' remittances still constitute the main source of income for a large number of households. Algeria's dependence on the world financial market increased steadily and the foreign debt constraints started to weigh heavily on the Algerian economy since the oil shock of 1986. Algeria's dependence on the world oil market is basic as oil and gas revenues constituted and still constitute about $98 \%$ of foreign earnings and about $60 \%$ of the budget receipts. Thus, Algeria's access to foreign borrowing hinges very much on the performance of oil and gas exports.

\section{The Allocation of Algeria's Foreign Borrowing}

In Algeria, foreign finance has essentially been raised by the government, the public enterprises and the national financial institutions. The Algerian private sector has been excluded from the circles of foreign borrowing. And because Algeria's currency (dinar) is inconvertible, foreign loans are guaranteed by the government. Foreign funds have been raised to contribute to the financing of planned public investments. In this sense, the allocation of external funds was carried out within the general framework of the government's development policy.

Over the period 1962-1969, the approved foreign funds, excluding French "aid", totalled more than AD 1,084bn (some US\$ 271mn), of which nearly $46 \%$ were grants (BAD 1971). They were approved by the socialist countries and were allocated to finance the import of capital goods, technical assistance and feasibility studies. It should be noted, however, that the industrial sector absorbed more than $60 \%$ of the total foreign credits, whereas agriculture received a mere $1.6 \%$. According to BAD's (1971) figures, more than twothirds of the credits allocated to the industrial sector went to mining with nearly $28 \%$, steel $28 \%$ and mechanical industries $16.5 \%$. The oil and gas sector received just $5.0 \%$ of the total credits allocated to the industrial sector. Thus, during this period the allocation of the foreign funds seems to have been in line with the government's purpose of building an industrial basis. However, this period was characterized by a lack of an efficient financial system and, therefore, a low absorption capacity of the available financial resources. The utilized foreign credits represented about $55.4 \%$ of the total approved foreign credits and totalled about AD 600.8mn (some US\$150mn) (BAD 1971).

Over the period 1970-1979, the government created a national financing structure and defined the sources and modalities of financing investment operations. This enabled the government to channel both domestic and external resources to planned development programmes. During this period, it borrowed 
extensively abroad despite unfavourable international financial conditions and significant increases in oil revenues. According to World Bank statistics (19801983), Algeria's foreign debt went from US\$ 937mn in 1970 to nearly US\$ $15 \mathrm{bn}$ in 1979. This happened at a time when Algeria's oil revenues increased from AD 3.1bn (about US\$ 775mn) in 1971 to AD 35.8bn (about US\$ 8.95) in 1979 (ONS 1987). Over this period, Algeria injected all its oil revenues in national development programmes, unlike the Arab Gulf States which invested a major part of their oil earnings abroad, mainly in the West. Foreign funds were essentially raised to help cover the import of capital goods and technical services and, therefore, were used to foster Algeria's domestic capital accumulation.

Throughout 1970-1979, Algeria's massive borrowing was predominantly composed of commercial loans, but also of substantial bilateral and multilateral loans. Commercial loans were of two types: supplier credits and private bank credits. Supplier credits represented $30.6 \%$ of total Algeria's foreign debt in 1974 before declining to nearly 26\% in 1979 (World Bank 1980-1983). As to the share of private bank loans, it remained higher throughout the 1970s and increased from nearly $40 \%$ in 1974 to about $60 \%$ in 1979 . By contrast, the share of governmental loans was on the decrease, falling from $30 \%$ in 1974 to about $12.6 \%$ in 1979 . Unlike the period of 1962-1969, the great majority of the foreign loans obtained during 1970-1979 were approved by the industrial and banking companies of OECD countries. According to some figures (EIU 19861987: 50), Algeria's total debt to OECD countries was still around US\$ $14.629 \mathrm{bn}$ at the end of 1982 . More importantly, the loans raised on the world financial market were of higher interest rates and reduced maturity periods. Inertest rates fluctuated between $7.6 \%$ in 1974 and $8.93 \%$ in 1978. And maturity periods ranged from 6.9 to 10.5 years during the same period (MPAT 1980: 289). These unfavourable interest rates and maturity periods added to the heavy burden of Algeria's foreign debt which by the end of the 1970s started to constitute a serious drain on the country's resources.

During 1970-1979, foreign credits totalled about AD 57.450bn (some $14.36 \mathrm{bn}$ ) and represented more than $36 \%$ of the overall funds allocated to planned investments (BAD 1970-1979). However, most of these foreign credits went to the industrial and oil and gas sectors. These absorbed more than $90 \%$ of the foreign credits, but oil and gas alone received about 55\% (BAD 19701979). However, while giving priority to the development of the oil and gas sector, mechanical and electrical industries sector, and semi-finished products sector, Algeria did not allocate over this period adequate domestic and foreign credits to the development of capital goods industries. This policy has significantly affected the integration of Algeria's economy which remained dependent on imports for the renewal of most of its capital goods. More significantly, the level of domestic savings remained relatively low during the period in question, despite the government's austerity policy imposed on consumption.

The concentration of public investments in heavy industries and the excessive recourse to foreign resources during the period 1967-1979 have been 
strongly criticized as they resulted in dangerous sectoral and regional imbalances and in an unacceptable level of foreign borrowing. This has consequently led the Algerian government to adopt a new investment policy for the period 1980-1989, emphasizing the improvement of performance for the industrial sector, the satisfaction of the growing needs of the population and the reduction of the foreign debt (Nancy 1980: 603). As a result, Algeria's national income became divided in three principal components: investment, consumption and repayment of the foreign debt.

In line with the new investment policy, the Algerian government imposed a moratorium on foreign borrowing for the period 1980-1982 and accelerated the repayment of the foreign debt incurred during the 1970s. It stressed that investment in new projects should be carried out only when the funds were available from national revenues or from export credits. In this respect, it is worthwhile noting that Algeria seems to have realized the malign effects of foreign borrowing. As a result, Algeria's foreign debt dropped substantially. According to World Bank figures (1980-1983), it fell from US\$16.3bn in 1980 to US\$ $12.9 \mathrm{bn}$ in 1983 . This reduction in the foreign debt was made possible by the substantial trade surpluses achieved since 1979 due to a rigorous control of imports and significant increases in the value of oil and gas exports. These factors allowed Algeria to strengthen its financial position and improve its financial credibility on the financial market, contrary to other developing countries, such as Brazil and Mexico, which continued to borrow extensively abroad and eventually turned in the early 1980s to the IMF to reschedule their huge foreign debts.

However, Algeria's financial ease was short-lived. The decline of oil prices since 1982 and the need to maintain a higher rate of economic growth, while servicing foreign debt, forced Algeria to return to the world financial market for further borrowing, resulting in a renewed rise in the country's foreign debt. By the end of 1985, Algeria's foreign debt amounted once again to US\$ $18.9 \mathrm{bn}$ and OECD countries continued to be Algeria's main creditors (ARB 1986). France remained the principal donor with about $19.5 \%$ of the total foreign debt, before Japan (14\%), the USA (13.3\%) and West Germany (7.4\%) (Khader 1985: 99). The composition of foreign debt remained similar to that of the late 1970s. However, the new loans were characterized by much higher interest rates (between $8.3 \%$ and $9.8 \%$ ) and relatively stable maturity periods (ranging from 7.7 to 10.4 years) (Gazzo 1986: 35). These higher interest rates and maturity periods reflected the increasing costs of Algeria's external borrowing. They further added to the already heavy repayments of the country's foreign debt.

Unlike the foreign borrowing of the 1970s, the new external funds have been allocated not only to industry and oil and gas sectors, but also to new priority sectors, such as agriculture, hydraulics, light industries and infrastructure. This new development policy aimed to reduce the sectoral imbalances of the 1970s to help create an inter-sectoral and intra-sectoral integration of the country's economy. This new policy equally sought to 
contribute to the satisfaction of the social needs of a fast-growing Algerian population.

\section{The Impact of Foreign Borrowing on Algeria's Economy}

Contrary to expectations, the sharp rise in foreign borrowing to finance planned development investments proved to be cumbersome to Algeria's economy and society and has been used inefficiently. Higher interest rates, increasing prices of imported goods and services and fluctuating oil prices have undoubtedly worsened the problem of foreign borrowing. However, a large number of domestic factors have also contributed to the burden of foreign debt, such as poor performance of the public companies, low domestic saving, absence of economic rationality, poor management and absenteeism. Since 1977, Algeria's foreign debt servicing has become huge in absolute terms and in relation to exports and GDP. Indeed, Algeria's debt repayments amounted to AD 10.9bn (some US\$ 2.7bn) in 1979 and represented nearly $30 \%$ of exports and 10\% of GDP (MPAT 1980: 287).

Moreover, the policy of foreign borrowing did not take into account the renewal of capital goods. Public investments in this sector remained low and most of the public companies were in chronic deficit and, therefore, were unable to generate the necessary amortization resources. For instance, by the end of 1981 the national public companies paid back to the government a mere Ad 398mn (some US\$ 100mn) out of a total of AD 125.240bn (some US\$ 31.31bn) of accumulated loans (Bouyakoub 1987: 353). Indeed, productivity of the national economy remained low and did not increase with the upswing of public investments. For instance, in the industrial sector, to increase the value added of one Algerian dinar, Algeria needed to invest 11.2 dinars (Mutin 1999). And industrial production dropped by $25 \%$ in 1990 as compared to 1984. As a result, the renewal of Algeria's fixed capital remained dependent on imports from abroad. In such conditions, this could only be done through further foreign borrowing and/or through the use of the resources of future generations. This partly explains the persistence of the government's excessive spending in the industrial sector. The funds spent on the renewal of capital goods generated neither incomes nor jobs. They represented additional costs and weighed heavily on the country's economy during the 1980s and beyond.

Despite improvement in Algeria's economic balances during 1980-1985, the new process of external borrowing further increased the constraints of the country's foreign debt. Between 1980 and 1985 repayments on the foreign debt rocketed to AD 132.8bn (some US\$29.5bn) and represented an average of $36.2 \%$ of exports and an average of $11.4 \%$ of GDP (MPAT 1986). More importantly, Algeria's economy remained dominated by the oil and gas sector. The expansion of the latter continued to be at the expense of the other sectors: agriculture, housing, water supply, transport and health. Algeria's inability to diversify the national economy and to reduce reliance on oil and gas exports left the country's economy in an extremely vulnerable position and later 
strongly undermined economic growth and exacerbated the foreign debt repayment problem.

So it is ample clear that when injected in Algeria's economy, foreign borrowing bore extra costs and, therefore, it constituted a drain on Algeria's resources in general and foreign currency earnings in particular. Undoubtedly, foreign borrowing was much more beneficial to creditors and to donor countries. This is because the conditions set in loan contracts protect creditors against the effects of inflation and, hence, guarantee net transfer of profits. Furthermore, the flow of foreign capital to Algeria and to other developing countries in the form of loans allows donor countries, mainly Western, to continue selling their products at increasing prices, something which often enables them to alleviate their economic and social pressures at the expense of developing countries. These empirical findings seem to go against Bauer's view that commercial loans are more productive for developing countries. But Prasad, Rajan and others apparently got it quite right when they claimed that foreign capital by itself would not result in additional growth. The neo-Marxist view can also be applied to Algeria's case as foreign capital seems to have aggravated dependency relations instead of creating a self-reliant national economy. Thus, what has been achieved contradicts the developmental goals envisaged by Algeria's development strategy.

\section{The 1986 Oil Price Shock and the Worsening Foreign Debt Problem}

The oil crisis of 1986 has severely hit Algeria's economic and social development and the modalities of foreign debt repayment. In 1986 crude oil prices fell well below $\$ 10$ per barrel leading to more than $50 \%$ drop in Algeria's oil and gas earnings. These continued to decrease until the mid1990s. They fell from US\$ 12.7bn in 1985 to US\$ 5.6bn in 1986 and they were US\$ 4.4bn in 1987, US\$ 5.4bn in 1988, US\$ 7bn in 1989, US\$ 9.6bn in 1991, and between US\$ 6bn and US\$ 7bn until 1995 (Mutin 1999). As a result, Algeria's trade surplus dropped from US\$ 4.223bn in 1985 to a mere US\$ $177 \mathrm{mn}$ in 1986 . But this was achieved after a reduction of $20 \%$ of imports (IMF 1985-1987). Furthermore, Algeria's current account balance registered a large deficit of US\$2.230bn and the state budget resulted in a huge deficit of about US\$ 3.1bn (IMF 1985-1987). These financial imbalances led to a decline in Algeria's GDP of 14.8 per cent, falling from AD 250bn (about US\$ 55.55bn) in 1985 to AD 213 (about US\$ 47.33bn) in 1986 (ARB 1987: 8506). These rendered Algeria unable to maintain repayments on the foreign debt if not at the expense of investment and consumption or the return to a new process of heavy borrowing.

In 1987, in spite of huge repayments, Algeria's foreign debt rose to US\$ $22.3 \mathrm{bn}$ and the debt service amounted to an estimated US\$ $4.7 \mathrm{bn}$, representing a little less than 50\% of total exports (Benyahya 1988: 38). Moreover, Algeria's foreign currency reserves fell from US\$2.8bn in 1985 to US\$1.6bn in 1987 (IMF 1985-1987). So, it is ample clear that the foreign debt repayment 
was exhausting the country's resources and represented a real transfer of wealth to creditors. Indeed, they led to drastic cuts in public investments and spending. This, in turn, resulted in severe shortages of goods on the domestic market and sharp rises in commodity prices and unemployment. According to Mutin (1999), the rate of inflation soared to more than 15\%, unemployment increased to $26 \%$ of the working population and totalled 1.800 .000 in 1989 . Therefore, Korinek (2010) were right to say that reliance on external finance causes sudden stops, financial instability and drops in output and foreign reserves for the domestic economy.

Furthermore, Algeria's dependence on external resources seems to have contributed to the spread of corruption and embezzlement of public funds, particularly in the oil and gas sector. According to a former Algerian prime minister (as cited in Mutin 1999), the cost of corruption amounted to some US\$ $23 \mathrm{bn}$ during the 1980s, especially with the anti-shortage programme launched to mitigate the effects of plunging oil prices. Similarly, in its annual report, the BAD (2014) revealed that illicit capital flows from Algeria totalled US\$ $173.11 \mathrm{bn}$ over the period 1980-2009. These are particularly linked to corruption in the oil and gas sector, lack of transparency in public spending, briberies and tax evasion. Undoubtedly, this illicit capital flight has contributed to cost overruns in public sector investments, worsened the effects of Algeria's foreign debt and affected economic growth, especially during the period of economic and political crisis 1986-1995.

\section{Coping with Declining Oil Prices: Austerity Measures and Structural Adjustment}

Faced with a renewed foreign borrowing process, Algeria took a wide range of austerity measures and some structural adjustment policies to confront drastic declines in oil prices. The aim was to maintain growth and keep repayment on the foreign debt without damaging the social consensus and losing the balances of the national economy. Among the austerity measures taken we mention (Grand Maghreb 1986):

- suspension of imports by post on cash with order basis which was used mainly by private producers to obtain goods not available on the domestic market;

- reduction in the hard currency allowance given to Algerians travelling abroad, including pilgrims to Mecca, which amounted to AD 1,000 and $\mathrm{AD} 7,500$ per person respectively;

- reduction in the cost of medical treatments abroad;

- cuts in military expenditures which until then remained untouched;

- fifty percent reduction in the government subsidies to basic foodstuffs and other products;

- reduction of administrative personnel. For instance, in December 1986 about 30,000 jobs were lost (ARB 1986: 8781);

- cuts in imports, public investment and spending, including foreign technical assistance; 
- increase of fiscal basis and high taxes on luxurious goods;

- attraction of monetary funds in foreign currencies, particularly through allowing Algerians to open hard currency accounts.

In addition to these severe austerity measures, the Algerian government launched a privatization programme to mobilize private funds and to promote the role of the private sector in national development. This included the building sector, agriculture and food production, light industries, transport and other services, such as distribution networks.

Nevertheless, these austerity measures were unpopular and proved to be economically, socially and politically very costly. While enabling the government to keep repayment on the foreign debt, they led to the shortages of goods and services on the domestic market, higher inflation (more than 15\%), rising unemployment, and a drop in living standards. Moreover, these austerity measures accelerated social inequalities. They particularly affected the poor sections of Algeria's society, while a privileged minority continued to display its wealth openly. Moreover, they increased social tensions which broke out in riots in the country's big cities, particularly in Constantine and Setif in October 1986 and Algiers in October 1988. The resulting critical economic and social situation forced the government to initiate a new process of political and economic reforms in an attempt to water down social tensions and reorganize the country's economy.

Despite some improvements in the performance of some economic sectors like agriculture where Algeria managed to increase production and cut the bill of food imports from AD 10bn (about US\$ 2bn) in 1985 to AD 7.5bn (about US\$ 1.5bn) in 1987 (ARB 1987: 8583), the new reforms seemed to have done little to rescue the country's economy and society from the perils of decreasing oil revenues and rising foreign debt. The expected increase in alternative exports to compensate falling oil and gas earnings have not materialized. And compressed imports of intermediary and capital goods have significantly affected the output of public and private enterprises and, therefore, reduced their export potentials. This combined with other domestic and external obstacles, such as the world economic recession of the 1980s and related protectionist measures, made it difficult for Algeria to diversify its economy and continued to rely almost exclusively on oil and gas for exports and foreign currency earnings. Throughout the 1990s, the oil and gas industry still accounted for $98 \%$ of exports, about $60 \%$ of government revenues, and $30 \%$ of GDP.

Due to low oil prices, Algeria was forced to continue borrowing abroad to save the national economy from collapse and to service foreign debt. External debt rocketed to more than US\$27bn in 1990 and represented about $60 \%$ of Algeria's GDP and nearly 95\% of exports in the early 1990s (Mutin 1999). Debt service exceeded US\$ $7 \mathrm{bn}$ in 1991. Political instability, disappointing performance of the country's economy and stringent financial conditions eventually led the government to sign a standby agreement with the IMF in May 1994 to reschedule the foreign debt. This agreement imposed a structural 
adjustment policy requiring, among other things, a reduction in the budget deficit, cuts in government subsidies, and a devaluation of the Algerian dinar. This depreciated against the US dollar from AD 5,915 in 1988 to AD 35,059 in 1994.

The economic and social costs of the structural adjustment programme were very cumbersome. Production in the industrial and other sectors declined sharply, as a good number of deficient public enterprises closed down. As a result, unemployment rose to $29 \%$ in 2000 . Moreover, GDP per capita fell from US\$2,400 to US \$1,600 and the purchasing power of Algerian salaries and incomes decreased by $40 \%$ by the end of the 1990s. This seems to have contributed significantly to the increase of Algerian families living under the poverty line whose number reached 850,000 in 1995 (Mutin 1999).

\section{The Role of Oil Prices in Repaying the Foreign Debt and Boosting Economic Growth}

Algeria's oil reserves are limited but gas reserves are huge. In 1986, oil production rose to $667,000 \mathrm{bbl} / \mathrm{d}$ and that of gas more than $91.2 \mathrm{bn}$ cubic metres. Still, this did not help to restore the country's economic and social imbalances generated by dwindling oil prices. In fact, the scale of Algeria's oil and gas earnings depends largely on the prices rather than the volumes of oil and gas exports. The collapse of the oil prices in 1986 has demonstrated the key role of prices in regulating revenues and transferring wealth from one nation to another. This has been witnessed once again in 2009 when the prices of exported oil sharply dropped and the balance of current account went negative to about US\$ $4.1 \mathrm{bn}$. Indeed, high oil and gas prices would secure a rise in revenues and would help Algeria raise its gas exports and save its limited oil reserves. However, if the scale of oil and gas production is under the government's control, the level of prices is beyond its control. The latter is basically dependent on four external factors: OPEC's cohesion, growth in global oil demand, the evolution of non-OPEC output and, to some extent, the value of the US dollar.

In the absence of a dynamic production system outside hydrocarbons, Algeria continued to rely almost exclusively on this sector. According to (EIA 2014), Algeria remained a small producer and exporter of crude oil with an average production of $1.8 \mathrm{mn} \mathrm{bbl/d}$ and estimated exports of $750,000 \mathrm{bbl} / \mathrm{d}$ in 2013, and a relatively large producer and exporter of gas with a total production of $6.4 \mathrm{Tcf}$ and exports of $1.7 \mathrm{Tcf}$ in 2012. Due to limited volumes of oil and gas exports and no alternatives in sight, Algeria had to wait for a new surge in oil prices since the mid-1990s to restart reviving a moribund economy. Indeed, soaring world oil demand driven by a higher global economic growth (backed by higher growth rates in emerging economies) resulted in substantial increases in the prices of exported oil and gas. These rocketed to US\$ 147 per barrel in July 2008 before falling to US\$ 45 in April 2009. As a result, Algeria's exports totalled more than US\$393bn in revenues over the period 2000-2009 (Alawsat 2010). These enabled Algeria to alleviate its external and internal financial imbalances and to significantly reduce its foreign debt. The 
latter decreased from US\$23.5bn in 2003 to US\$ $15.5 \mathrm{bn}$ in 2006, and later fell to US\$ 4.4bn in 2011 and US\$ 3.39bn in 2013 (Alrroya 2010, TSA 2014). Moreover, Algeria's GDP grew to US\$ 125.9bn in 2007 and to US\$210.2bn in 2013. Algeria's foreign currency reserves climbed rapidly from US\$ $12 \mathrm{bn}$ in 2000 to about US\$ 99.3bn in 2007 (FRD 2008). According to the governor of the Algerian Central Bank (as cited in Alaswaq 2010, TSA 2014), this further rose to US\$ 148.9bn in 2009 and US\$ 194.2bn in 2013.

Moreover, the substantial increase in Algeria's oil and gas earnings helped the government to raise public spending to a total of US\$286bn over the period 2010-2014 (World Bank 2014). This resulted in a drop of unemployment, declining to 10.2 in 2009 against 15.7 in 2006 and a reduction in the budget deficit to $1 \%$ of GDP in 2013 but rose to 1.3 in 2014 (UAB 2014). Likewise, inflation declined from near $30 \%$ in the mid 1990s to 5.7 in 2009 and 3.3 in 2013 (IMF 2014). However, in spite of these improvements at the macro-economic level, Algeria's economic outlook remained bleak. The economic growth was only $3 \%$ in both 2007 and 2008, and rose to $3.9 \%$ in 2009 before falling to $2.8 \%$ in 2013. By contrast, Indonesia, which was an important oil producer and exporter during the 1970s and 1980s, achieved steady economic growth throughout the 1970s (averaging 8\%) and restored economic growth over 1986-1997 and 1999-2008 to reach in average 6.83 and $5.12 \%$ respectively (Gray 2002 and Suryahadi et al. 2012). Similarly, according to figures issued by the UAB (2014), Saudi Arabia's economy registered higher growth rates 8.6 in 2011, 5.6 in 2012 and 3.8\% in 2013. More significantly, Egypt's economy grew by 7.1 and $7.2 \%$ during 2007 and 2008 respectively, even though Egypt is not an oil exporter.

Moreover, the structure of the country's GDP remained roughly the same. The government's efforts which have been launched since 2000 to further encourage domestic and foreign investment outside the oil and gas sector have so far done little to diversify the economy and to promote non-oil exports. About half of the share of industry in Algeria's GDP continued to be attributable to the oil and gas sector. In fact, excluding the latter, the contribution of industry to GDP dropped from $15 \%$ in 1979 to just 5\% since 2007. This indicates that the industrial sector is still far behind to become the driver of economic growth. By contrast, Indonesia managed to turn the private sector and foreign investment into drivers of economic growth. Moreover, it managed to raise the share of industry to $19 \%$ of GDP and transformed the composition of its economy to become an important producer and exporter of food products and manufactured goods, including computer and communication services (Elias and Clare 2011). With a population of 242mn, now Indonesia has the fourth largest economy in East Asia after China Japan and South Korea and is the $15^{\text {th }}$ largest economy in the world in terms of purchasing power parity (Elias and Clare 2011).

Today the economic challenges of Algeria's development efforts are twofold: declining oil prices and decreasing oil and gas outputs. Oil production fell by $14.5 \%$ and dropped from 85.6 million tons in 2006 to 73.3 million tons in 2011 . And gas production fell by $32.6 \%$, going from 85 to 57.3 billion $\mathrm{cu} \mathrm{m}$ 
over the same period (TSA 2014). As a result, oil and gas exports, in terms of volume, fell by $25.6 \%$ during 2006-2011 and, in terms of value, dropped to US\$ 63.8bn in 2013 against US\$ 69.8bn in 2012 (EIA 2014). By contrast, Algeria's imports rocketed from US\$ 9.48bn in 2001 to US\$ 46.45bn in 2011 and to US\$ 55.1bn in 2013 (Alrroya 2012, TSA 2014). It is important to note that Algeria's food imports rose to US\$ 9.75bn in 2011 and represented more than $21 \%$ of total imports US\$ 46bn (Alrroya 2012). This indicates that Algeria's food dependence is on the increase. If this rise in total imports continues, Algeria's balance of payments will suffer serious deficits for many years to come. These financial imbalances, in current circumstances, can only be restored through the use of foreign currency reserves which have already dropped to US\$178bn at the end of December 2014.

The balance of payments surplus has also shrunk to a mere US\$133mn in 2013 due to declining oil and gas prices and increasing imports. Likewise, unemployment is forecast to increase to 10.8 in 2014 and 11.3 in 2015 (TSA 2014). This trend is expected to continue in 2014 and 2015 and is likely to remain so as long as the prices of oil and gas kept low. The IMF (2014) has reported that, in view of declining oil prices and revenues since the second half of 2014, Algeria's balance of current account is to be negative (-3\% of GDP) this year and (-2.9 of GDP) in 2015. This is likely to lead to further contractions in Algeria's foreign currency reserves and growth rates in the years to come. Thus, in a shaky global oil market and an uncertain national economic outlook, the Algerian government should be more prudent in its spending policy to maintain its financial balances and to avoid a new process of foreign borrowing that could further jeopardize the country's economic and social development.

\section{Conclusions}

From the preceding analyses we come to conclude that the claim that foreign capital is necessary for economic growth and development seems to be quite illusive. Foreign capital in developing countries has proved, in many cases, to be less effective, if not ineffective, in relieving bottlenecks and inducing economic growth and development. It is neither a substitute for domestic savings nor a driving force for economic growth. Indeed, the developing countries which received foreign "aid" and borrowed extensively on the world financial market, such as Algeria, do not appear to have achieved yet a self-sustained growth. Foreign and domestic resources allocated for investment have either been wasted or used inefficiently. They have neither restored economic and social imbalances nor generated a dynamic economy capable of raising domestic savings and cutting reliance on external resources. In fact, recourse to foreign finance aggravated dependency relations and created a systematic transfer of wealth from recipient to donor countries. In addition, it generated corruption in the political and bureaucratic circles of 
developing countries which turned now into a serious obstacle to their development.

Although the foreign funds used in development were limited they had farreaching effects on the Algerian economy and society. They seem to have aggravated sectoral imbalances and strengthened dependency relations. Moreover, foreign loans weighed heavily on the government's finances and served to transfer important funds to creditor countries. Without the recent rise in oil prices Algeria would have found it extremely hard to bring the foreign debt to a much reduced level.

However, reliance on oil and gas revenues and an inefficient bureaucracy seem to have also contributed to low economic growth rates. Public companies have badly used their resources and failed to raise productivity. Moreover, the important efforts carried out by the government since the oil price shock of 1986 to diversify the economy have so far failed to set up an industrial basis outside the oil sector capable of generating economic growth and wealth. Economic growth is sill dependent on external resources (the revenues of oil and gas exports) and government spending (the allocation of oil revenues) which are highly cyclical. Furthermore, the contribution of the private sector and foreign investments to Algeria's economic development remains limited. With its present-day potentials, the private sector appears to still have a long way to go to become a driver of economic growth.

Indeed, despite the huge funds mobilized for development since 2000 growth rates remain relatively low and the oil and gas sector is still the backbone of the Algerian economy. It still constitutes about $97 \%$ of exports, $61 \%$ of the budget receipts and $30 \%$ of GDP. This clearly indicates that it is not capital that is lacking for growth and development in Algeria. Rather, it is the way funds are allocated and the way investments are carried out which seem to be behind the setbacks of Algeria's economic and social development. Apparently, here Bauer is right to claim that development depends on people's capacities, motivations and social and political institutions.

In an uncertain global energy market, Algeria needs to do a lot to create a more favourable business climate to boost domestic and foreign investments outside the energy sector. Further drastic declines in oil and gas prices could erode Algeria's substantial foreign reserves and bring the country's economy to a standstill. Thus, the government is urgently required to review its spending and development policies, reorganize its economy and curb corruption to face the various challenges ahead and to secure resources for future generations.

\section{References}

Alaswaq A (2010) 2009 increase in Algeria's Foreign Currency Reserves in 2009]. Available from: www.alaswaq.net.

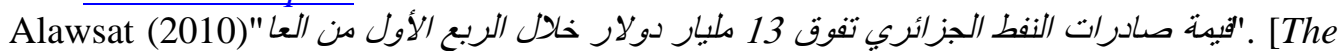
Value of Algeria's Oil Exports are More than US\$13bn in the First Quarter of the Year]. 11444, March 29. 
Alrroya (2010) [Algeria Expects a 4\% Growth in 2011]. Available from: http://bit.ly/laNJEDU

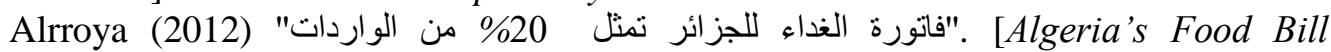
Represents 20\% of Imports]. Available from: http://bit.ly/lGdZUt2.

ARB-Africa Research Bulletin (1974) 11(3 - April 30).

ARB-Africa Research Bulletin (1980) 17(6 - June 30).

ARB-Africa Research Bulletin (1986) 23, 24 (5 - June 30/7 - August 31).

ARB-Africa Research Bulletin (1987) 23, 24 (12 - January 31/2 - March 31).

BAD-Banque Africaine de Développement [African Bank of Development] (2014) Rapport Annuel 2013 [Annual Report 2013].

BAD-Banque Algérienne de Développement [Algerian Bank of Development] (1971) Rapport d'Activité 1971 [Activity Report 1971]. Algeria: Ministère des Finances.

BAD-Banque Algérienne de Développement [Algerian Bank of Development] (19701979) Rapports d'Activité Annuels [Annual Activity Reports]. Algeria: Ministère des Finances.

Bauer PT (1971) Dissent on Development: Studies and Debates in Development Economics. London: Weidenfeld and Nicolson.

Benyahya M (1988) Chadli's promise of Perestroika. The Middle East (161).

Bouyakoub A (1987) Le Cycle d'Investissements Global [Global Investment Circle]. In A. Henni. Monnaie, Crédit et Financement en Algérie. Algeria: C.R.E.A.D.

Brown MB (1974) The Economics of Imperialism. London: Penguin Books.

Danziger MP (2010) G20 Pledges to Help Poor Meet MDGs: Financial Transparency Can Help. Available from: http://bit.ly/lKlysQz.

Dornbusch R, Werner A, Calvo G., Fischer S (1994) Mexico: stabilization, reform and no growth. Brookings Papers on Economic Activity 1: 253-315.

Dornbusch R, Goldfajn I, Valdés RO (1995) Currency crises and collapses. Brookings Papers on Economic Activity 2: 219-293.

EIA-US Energy Information Administration (2014) Country Analysis Brief: Algeria. Available from: http://1.usa.gov/lDbzchd.

EIU-The Economist Intelligence Unit (1986-1987) Country Profile. Algeria: EIU.

Elias S, Clare N (2011) The Growth and Development of the Indonesian Economy. Reserve Bank of Australia, December Quarter, Available from: www.rba.gov.au.

FRD-Federal Research Division (2008, May) Country Profile: Algeria, Liabrary of Congress.

Gazzo Y (1986) Le Monde Arabe Face à l'Endettement: le Cas des Pays du Maghreb [The Arab World in Front of Debt: The case of Maghreb Countries] MaghrebMachrek (114).

Grand Maghreb (1986) Numbers 47, 48, 49, 53.

Gray M (2002) Foreign direct investment and recovery in Indonesia: recent events and their impact, IPA Backgrounder 14(2). Available from: http://bit.ly/1zFNIwv.

Hayter T (1971) Aid as Imperialism. USA: Penguin Books, Ecoks.

IMF-International Monetary Fund (1985-1987) International Financial Statistics.

IMF-International Monetary Fund (2014, October) World Economic Outlook Report.

Kar D, Spangers J (2014) Illicit Financial Flows from Developing Countries: 20032012, GFI. Available from: http://bit.ly/lPahhPH.

Khader B (1985) L'Arabie Saoudite et l'Algérie Face à la Crise Pétrolière 1986 [Saudi Arabia and Algeria Facing the Oil Crisis 1986]. Annuaire de l'Afrique du Nord. Aix-en-Provence: CRESM.

Korinek A (2010) Regulating Capital Flows to Emerging Markets: Design and Implementation Issues. Available from: http://bit.ly/lOanObb. 
Maizels A, Nissanke MK (1984) Motivations for aid to developing countries. World Development 12(9).

MPAT-Ministère de la Planification et de l'Aménagement du Territoire [Ministry of Planning] (1980) Synthèse du Bilan Economique et Social de la Décennie 19671978 [Summary of the Economic and Social Review of the Decade 1967-1978] Algeria: MPAT.

MPAT-Ministère de la Planification et de l'Aménagement du Territoire [Ministry of Planning] (1986). Rapports Annuels d'Exécution du plan 1980-1986 [Annual Reports of Execution Plan 1980-1986]. Algeria: MPAT.

Mutin G (1999) Evolution Economique de l'Algérie Depuis l'Indépendance 19621995 [Economic Evolution of Algeria since Independence 1962-1995]. Available from: http://bit.ly/lHdJEve.

Nancy M (1980) Chronique Economique de l'Algérie [Economic Chronicle of Algeria]. Annuaire de l'Afrique du Nord. Aix-en-Provence: CRESM.

ONS-Office National des Statistiques (1984) L'Algérie en Quelques Chiffres [The Few Figures in Algeria]. Algeria: ONS.

ONS-Office National des Statistiques (1987) Statistiques 1962-1986 [Statistics 19621986] (15), Algeria: ONS.

Palloix C (1980) Industrialisation et Financement Lors des Deux Plans Quadriennaux 1970-1977 [Industrialization and Financing During Two Quadrennial Plans], Revue Tiers Monde 21(83).

Prasad E, Rajan R, Subramanian A (2006) Foreign capital and economic growth. IMF Research Department. Available from: http://bit.ly/lOan7DF.

SEP-Secrétariat d'Etat au Plan (1975) Direction des Statistiques et de la Comptabilité Nationale [Direction of Statistics and National Accounting]. Annuaire Statistiques de l'Algérie. Algeria: SEP.

Suryahadi A, Hadidjaja G, Sumarto S (2012) Economic Growth and Poverty Reduction in Indonesia Before and After the Asian Financial Crisis. The SMERU Research Institute.

Symonds R (1970) International Targets for Development. London: Faber \& Faber.

TSA-Tout Sur l'Algérie (2014) L'Excédent Commercial au Plus Bas et Stagnation des Réserves de Change [The Surplus Sales at Lowest Stagnation and Exchange Reserves]. Available from: http://bit.ly/lDbylhU.

" لمحة عن 2014 و 2015" (2014) (n) ]An Overview of Arab Economic Developments in 2014-2015]. Available from: http://bit.ly/1DxlODl.

Webster A (1984) Introduction to the Sociology of Development. London: Macmillan. World Bank (2014) Algeria. Available from: http://bit.ly/1bfyAQo.

World Bank (1980-1983) World Debt Tables. Available from: http://bit.ly/1bfyAQo. 
